$1-1-1969$

\title{
Effect of root pruning and provenance on shoot and root growth of scotch pine seedlings
}

James H. Brown

Follow this and additional works at: https://researchrepository.wvu.edu/ wv_agricultural_and_forestry_experiment_station_bulletins

\section{Digital Commons Citation}

Brown, James H., "Effect of root pruning and provenance on shoot and root growth of scotch pine seedlings" (1969). West Virginia Agricultural and Forestry Experiment Station Bulletins. 584T.

https://researchrepository.wvu.edu/wv_agricultural_and_forestry_experiment_station_bulletins/690 @ WVU. It has been accepted for inclusion in West Virginia Agricultural and Forestry Experiment Station Bulletins by an authorized administrator of The Research Repository @ WVU. For more information, please contact ian.harmon@mail.wvu.edu. 

Digitized by the Internet Archive in 2010 with funding from

Lyrasis Members and Sloan Foundation 


\author{
AUTHOR \\ JAMES H. BRown \\ is Associate Silviculturist
}

WEST VIRGINIA UNIVERSITY Agricultural EXPERIMENTAL STATION COLlege of Agriculture and Forestry

A. H. VAnLandingham, Director

MORGANTOWN 


\section{Effect of Root Pruning and Provenance}

\section{on Shoot and Root Growth of}

Scotch Pine Seedlings'

\section{JAMES H. BROWN}

TUMEROUS STUDIES have shown that survival varies when 1 tree seedlings are transplanted at different times of the year. In general, these studies have shown that survival is lowest when transplanting is done during the period when top growth is most active. Drought has been cited as the major reason for seedling mortality and this has been related to inability of seedling root systems to supply moisture as rapidly as it is lost from the tops. The inability to supply sufficient moisture is caused, in part, by greater intake and loss of water during the period when height growth is most active (Kramer, 1932 and 1943: Kozlowski, 1943: Gibbs, 1958).

It has also been shown that regeneration of new roots following transplanting varies with time of year. It is apparently greatest in late fall after top growth is completed and in early spring before top growth commences, and is lowest during the spring and summer months when top growth is taking place (Neff and O'Rourke, 1951; Wilcox, 1955; Stone, 1955; Stone et al.. 1959a, 1959b, 1962, 1963).

Studies have also shown that there are decided differences in the seasonal height growth patterns of different provenances of the same tree species. Wright and Bull (1963) reported variation of over two months in date of first-year bud set between the most northerly and southerly provenances of Scotch Pine. Brown (1967) found differences in seasonal rate of top growth and length of the growth period for five provenances of Scotch pine from western Europe.

The purposes of the study reported here were: (1) to investigate the interrelationships between top growth, root growth and root regeneration potential of seedlings of different Scotch pine provenances:

1This paper is based on part of a $\mathrm{PhD}$ thesis submitted to Michigan State University. The work was supported in part by regional research funds from the $U$. $S$. Department of Agriculture under project NC-51, "Tree Improvement through Selection and Breeding" and in part by funds from Hatch 119. "Production of Plantation Grown Christmas Trees in West Virginia." 
and (2) to study variations in survival of seedlings of those provenances when transplanted with different intensities of root pruning at different times of the year.

\section{Procedure}

Five seed sources of Scotch pine were selected, representing a northsouth gradient through western Europe (Table 1). These seed lots were originally collected for use in the Scotch pine provenance study conducted by Wright and Bull (1963). Seed was sown in the Michigan State University Forestry Research Center Nursery at East Lansing, Michigan, in May 1965 using a randomized complete block design with four replications.

On July 20, approximately one month after germination, six seedlings from each seed source in each replicate were lifted from the nursery beds without visible damage to any roots. Two seedlings from each seed source and replicate were subjected to each of three intensities of root-pruning - removal of all lateral roots over three millimeters in length; removal of half the lateral root system; and removal of no roots. In removing half the lateral root system, laterals were spread out to their full extent and individual laterals were cut at approximately their midpoint.

: After root-pruning, each seedling was transplanted into an individual container and the roots were covered with a potting mixture consisting of $2 / 3$ (by volume) 20 - to 40 -mesh quartz sand and $1 / 3$ shredded peat moss. This mixture contained complete fertilizer sufficient to provide $50 \mathrm{ppm} \mathrm{N}, 25 \mathrm{ppm} \mathrm{P}_{2} \mathrm{O}_{5}$, and $50 \mathrm{ppm} \mathrm{K}_{2} \mathrm{O}$. The seedlings were placed in a greenhouse in the same order as in the nursery beds.

\section{TABLE 1}

Location and Climate at Place of Origin of Scotch Pine Provenances Used in Study

\begin{tabular}{|c|c|c|c|c|c|c|c|}
\hline \multirow{2}{*}{$\begin{array}{l}\text { MSFG No. and } \\
\text { Country of } \\
\text { Origin (a) }\end{array}$} & \multirow[b]{2}{*}{ Variety (b) } & \multicolumn{3}{|c|}{ Location } & \multirow{2}{*}{$\begin{array}{c}\text { Avg. } \\
\text { Annual } \\
\text { Temp. }\end{array}$} & \multirow{2}{*}{$\begin{array}{l}\text { Mos. } \\
\text { Above } \\
6^{\circ} \mathrm{C}\end{array}$} & \multirow{2}{*}{$\begin{array}{l}\text { Annual } \\
\text { Precip. }\end{array}$} \\
\hline & & $\begin{array}{l}\text { Lat. } \\
\mathbf{N}\end{array}$ & $\begin{array}{c}\text { Long. } \\
\text { E }\end{array}$ & Elev. & & & \\
\hline & & $\circ$ & $\circ$ & feet & ${ }^{\circ} \mathrm{C}$ & No. & $\mathbf{m m}$. \\
\hline 218 SPAin & iberica & 40.0 & -5.3 & 3700 & 10.0 & 7 & 366 \\
\hline 240 FRAnce & aquitana & 42.6 & 2.1 & 4700 & 5.9 & 6 & 799 \\
\hline 251 GERmany & haguenensis & 49.1 & 8.1 & 500 & 9.9 & 7 & 536 \\
\hline 550 S-SWEden & tigensis & 55.9 & 14.1 & 100 & 6.9 & 6 & 468 \\
\hline $548 \mathrm{~N}$-SWEden & lapponica & 63.5 & 18.7 & 700 & 2.0 & 4 & 568 \\
\hline
\end{tabular}

(a) Numbers are those used in the Michigan State Forest Genetics accession record and are the same as those reported by Wright and Bull (1963) and Wright et al. (1966).

(b) Scotch pine varietal designations as assigned to these provenances by Ruby (1964), 
They were watered sufficiently to maintain mosture in the potting mixture at a level slightly below field capacity. After 30 days, trees were removed from the pots and the root systems were carefully washed. Measurements were made on survival, top length, total lateral root length, and absorbing lateral root length. Absorbing lateral length was defined as the white portion of the lateral root system and was also approximately equal to the amount of root elongation which occurred during the 30-day period when the seedlings were in the greenhouse.

Lifting from the nursery, root-pruning and transplanting were repeated at monthly intervals until November 20 , when the final (fifth) transplanting was made. The entire study therefore used a split-split plot experimental design, with time of transplanting as the main effect. the seed source as the sub-plot effect, and intensity of root pruning as the sub-sub-plot effect, with two-tree plots replicated four times.

Statistical analyses for all data were made for three of the variables measured - survival, top length, and absorbing lateral root length. Analyses of total lateral root length were made only for seedlings transplanted in September, October, and November with no root-pruning. High mortality after July and August transplanting resulted in many missing plots.

\section{Results}

\section{SURVIVAL}

Survival varied significantly due to time of transplanting, seed source, and treatment (Table 2; Appendix Table 1). Survival was low for all trees transplanted in mid-summer, especially for those which suffered the most drastic root pruning. Survival was higher for trees transplanted in September and nearly 100 per cent for trees transplanted later.

There were significant ( 1 per cent level) time-seed source interactions. Seedlings of the three most southerly origins (SPA, FRA, and GER) had very low survival after transplantings in July and August and achieved 100 per cent survival only after November transplantings. Seedlings of the two Swedish origins had appreciably better survival in midsummer and reached 100 per cent survival after October lifting.

When seed sources were considered independently of time of transplanting, the north-Swedish source had significantly more (67 per cent) living trees than other sources. The south-Swedish origin had the next highest survival ( 57 per cent). Average survival of the three southern sources was 46 to 47 per cent.

The effects of transplanting on survival also varied with intensity 
of root pruning. Removal of all the lateral roots gave significantly lower survival than did treatments which removed none and one-half of the lateral root systems. Treatment-seed source interactions were not significant but treatment-time interactions were. Trees having no or

\section{TABLE 2}

\section{Survival and Height of Scotch Pine Provenances One Month After Transplanting With Various Intensities of Root Pruning}

\begin{tabular}{|c|c|c|c|c|c|}
\hline \multirow[t]{2}{*}{$\begin{array}{l}\text { Date of } \\
\text { Lifting }\end{array}$} & \multirow[t]{2}{*}{$\begin{array}{l}\text { MSFG } \\
\text { No. and } \\
\text { Origin }\end{array}$} & \multicolumn{3}{|c|}{$\begin{array}{l}\text { Survival after removal } \\
\text { of the following portion of } \\
\text { lateral roots present at the } \\
\text { time of lifting }\end{array}$} & \multirow[t]{2}{*}{ Height (a) } \\
\hline & & None & Half & All & \\
\hline July 20 & $\begin{array}{ll}218 & \text { SPA } \\
240 & \text { FRA } \\
251 & \text { GER } \\
550 & \text { S-SWE } \\
548 & \text { N-SWE }\end{array}$ & $\begin{array}{r}12 \\
12 \\
0 \\
25 \\
25\end{array}$ & $\begin{array}{c}\text { per cer } \\
12 \\
12 \\
12 \\
12 \\
12\end{array}$ & $\begin{array}{l}0 \\
0 \\
0 \\
0 \\
0\end{array}$ & $\begin{array}{l}\text { mm. } \\
31 \\
26 \\
31 \\
30 \\
29\end{array}$ \\
\hline Aug. 20 & $\begin{array}{ll}218 & \text { SPA } \\
240 & \text { FRA } \\
251 & \text { GER } \\
550 & \text { S-SWE } \\
548 & \text { N-SWE }\end{array}$ & $\begin{array}{r}12 \\
0 \\
12 \\
38 \\
50\end{array}$ & $\begin{array}{r}12 \\
12 \\
0 \\
25 \\
38\end{array}$ & $\begin{array}{r}0 \\
0 \\
0 \\
0 \\
12\end{array}$ & $\begin{array}{l}55 \\
47 \\
63 \\
54 \\
44\end{array}$ \\
\hline Sept. 20 & $\begin{array}{ll}218 & \text { SPA } \\
240 & \text { FRA } \\
251 & \text { GER } \\
550 & \text { S-SWE } \\
548 & \text { N-SWE }\end{array}$ & $\begin{array}{r}62 \\
50 \\
50 \\
75 \\
100\end{array}$ & $\begin{array}{r}75 \\
62 \\
62 \\
75 \\
100\end{array}$ & $\begin{array}{r}0 \\
0 \\
0 \\
0 \\
62\end{array}$ & $\begin{array}{r}72 \\
60 \\
101 \\
70 \\
53\end{array}$ \\
\hline Oct. 20 & $\begin{array}{ll}218 & \text { SPA } \\
240 & \text { FRA } \\
251 & \text { GER } \\
550 & \text { S-SWE } \\
548 & \text { N-SWE }\end{array}$ & $\begin{array}{l}100 \\
100 \\
100 \\
100 \\
100\end{array}$ & $\begin{array}{l}100 \\
100 \\
100 \\
100 \\
100\end{array}$ & $\begin{array}{r}25 \\
50 \\
62 \\
100 \\
100\end{array}$ & $\begin{array}{r}70 \\
61 \\
100 \\
71 \\
51\end{array}$ \\
\hline Nov. 20 & $\begin{array}{ll}218 & \text { SPA } \\
240 & \text { FRA } \\
251 & \text { GER } \\
550 & \text { S-SWE } \\
548 & \text { N-SWE }\end{array}$ & $\begin{array}{l}100 \\
100 \\
100 \\
100 \\
100\end{array}$ & $\begin{array}{l}100 \\
100 \\
100 \\
100 \\
100\end{array}$ & $\begin{array}{r}88 \\
100 \\
100 \\
100 \\
100\end{array}$ & $\begin{array}{r}71 \\
62 \\
100 \\
70 \\
53\end{array}$ \\
\hline
\end{tabular}

(a) There were no significant differences in height for seedlings receiving different intensities of root pruning.

one-half root removal had low survival from July and August transplantings. In later liftings, the number of living trees increased, reaching 100 per cent in October and November. For trees having fullroot pruning, there was no survival (except for N-SWE) until after the October transplanting. 


\section{TOP GROWTH}

Most top growth occurred before transplanting, therefore it was affected significantly by time of measurement, sesd source, and timeseed source interaction. There were no significant differences between seedlings receiving different intensities of root pruning (Table 2; Appendix Table 1).

Top growth was completed in all five seed sources by September 20. As shown in Figure 1 and Tables 2 and 3, the German provenance had a relatively rapid and constant growth rate throughout the height growth period. Approximately one-third of the total elongation occurred during each of the three months preceding September 20. Seedlings from northern Sweden had a decidedly different pattern. Over one-half of the total growth was completed by July 20 and over 80 per cent was completed by August 20. Growth patterns of the other three sources were similar, with 43 per cent of total elongation completed by July 20 and approximately 75 per cent completed by August 20.

German seedlings grew $100 \mathrm{~mm}$. tall, almost $30 \mathrm{~mm}$. more than the next best sources from Spain and southern Sweden. Total top growth for the French source was about $60 \mathrm{~mm}$., while the maximum attained by north-Swedish seedlings was a little over $50 \mathrm{~mm}$.

\section{TOTAL LATERAL ROOT LENGTH}

Only data for those trees which received no root pruning and were transplanted from September to November were analyzed statistically (Appendix Table 2). Differences due to time of transplanting, seed source, and time-seed source interaction were significant. Root growth was very slow during early- to mid-summer when top growth was greatest, but root growth continued much later than did top growth (Tables 3, 4; Figure 1.)

Although data for July and August transplantings were not analyzed statistically, there were probably time-seed source interactions (Figure 1). The two Swedish provenances had the greatest total lateral root lengths after the first transplanting, while roots of German seedlings were longest after later transplantings. Spanish and French trees produced few lateral roots in the early months and did not catch up to the north-Swedish trees until October. Roots of October transplanted trees of all provenances were 90 to 97 per cent as long as those of November transplanted ones; there were no significant time-seed source interactions for these months. 


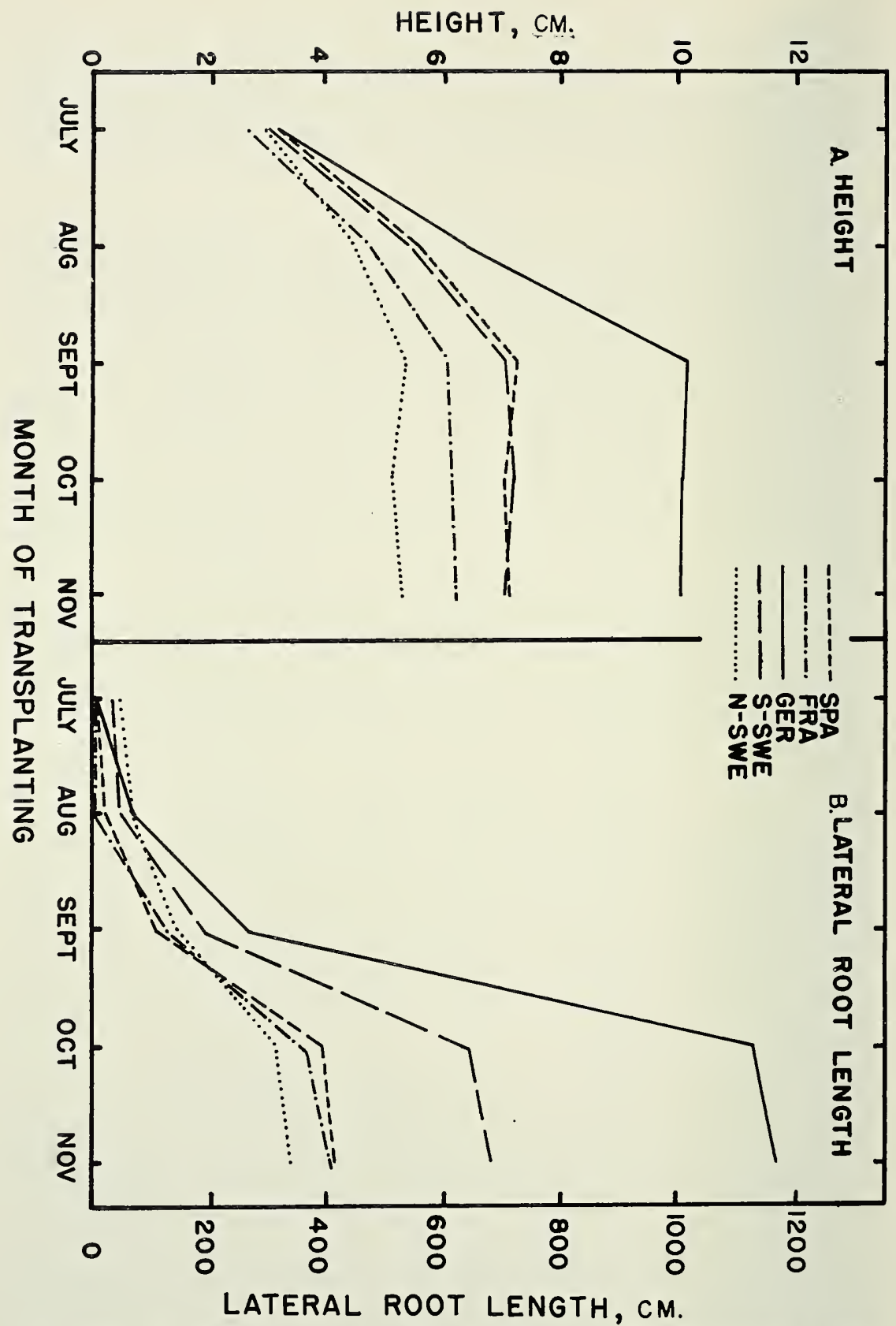

Figure 1. Height and total lateral root length for five provenances of Scotch pine transplanted with no root pruning at five different times. 
Roots of German seedlings had a maximum total lateral length which was nearly 70 per cent more than for the source (S-SWE) with the next longest lateral root length. Spanish and French seedlings had total lateral lengths of about $400 \mathrm{~cm}$., while trees from northern Sweden attained a maximum lateral extent of $340 \mathrm{~cm}$.

\section{ABSORBING LATERAL LENGTH}

The "absorbing" (white) lateral roots were approximately equal to the amount of lateral root growth which took place during the 30 day period when seedlings were in the greenhouse. This new lateral growth originated from two sources: new growth on the tips of exist-

\section{TABLE 3}

\section{Percentage of End-of-Season Growth Attained at Various Measurement Dates (30 Days After Lifting Dates)}

\begin{tabular}{|c|c|c|c|c|c|c|}
\hline \multirow[t]{2}{*}{$\begin{array}{l}\text { MSFG } \\
\text { No. and } \\
\text { Origin }\end{array}$} & \multirow[t]{2}{*}{$\begin{array}{l}\text { Lifting } \\
\text { Date }\end{array}$} & \multirow{2}{*}{\multicolumn{2}{|c|}{ 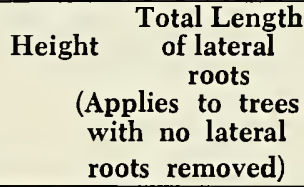 }} & \multicolumn{3}{|c|}{$\begin{array}{l}\text { Length of absorbing } \\
\text { roots after removal } \\
\text { of following portion } \\
\text { of lateral roots at } \\
\text { lifting time }\end{array}$} \\
\hline & & & & None & Half & All \\
\hline & & \multicolumn{5}{|c|}{ Per cent of end-of-season growth } \\
\hline 218 SPA & $\begin{array}{l}\text { July } 20 \\
\text { Aug. } 20 \\
\text { Sept. } 20 \\
\text { Oct. } 20 \\
\text { Nov. } 20\end{array}$ & $\begin{array}{r}43 \\
76 \\
100 \\
100 \\
100\end{array}$ & $\begin{array}{r}1 \\
5 \\
26 \\
95 \\
100\end{array}$ & $\begin{array}{r}1 \\
9 \\
39 \\
100 \\
100\end{array}$ & $\begin{array}{r}2 \\
6 \\
60 \\
100 \\
100\end{array}$ & $\begin{array}{r}7 \\
94 \\
100\end{array}$ \\
\hline 240 FRA & $\begin{array}{l}\text { July } 20 \\
\text { Aug. } 20 \\
\text { Sept. } 20 \\
\text { Oct. } 20 \\
\text { Nov. } 20\end{array}$ & $\begin{array}{r}43 \\
76 \\
100 \\
100 \\
100\end{array}$ & $\begin{array}{r}\frac{1}{31} \\
89 \\
100\end{array}$ & $\begin{array}{r}\frac{4}{36} \\
88 \\
100\end{array}$ & $\begin{array}{r}0 \\
6 \\
47 \\
90 \\
100\end{array}$ & $\begin{array}{r}7 \\
86 \\
100\end{array}$ \\
\hline 251 GER & $\begin{array}{l}\text { July } 20 \\
\text { Aug. } 20 \\
\text { Sept. } 20 \\
\text { Oct. } 20 \\
\text { Nov. } 20\end{array}$ & $\begin{array}{r}31 \\
63 \\
100 \\
100 \\
100\end{array}$ & $\begin{array}{r}-6 \\
23 \\
97 \\
100\end{array}$ & $\begin{array}{r}-6 \\
33 \\
100 \\
100\end{array}$ & $\begin{array}{r}\frac{1}{22} \\
96 \\
100\end{array}$ & $\begin{array}{l}\overline{-} \\
1 \overline{100} \\
100\end{array}$ \\
\hline $550 \mathrm{~S}-\mathrm{SWE}$ & $\begin{array}{l}\text { July } 20 \\
\text { Aug. } 20 \\
\text { Sept. } 20 \\
\text { Oct. } 20 \\
\text { Nov. } 20\end{array}$ & $\begin{array}{r}43 \\
78 \\
100 \\
100 \\
100\end{array}$ & $\begin{array}{r}5 \\
7 \\
27 \\
94 \\
100\end{array}$ & $\begin{array}{r}4 \\
7 \\
34 \\
98 \\
100\end{array}$ & $\begin{array}{r}1 \\
5 \\
37 \\
98 \\
100\end{array}$ & $\begin{array}{l}7 \\
17 \\
100\end{array}$ \\
\hline 548 N-SWE & $\begin{array}{l}\text { July } 20 \\
\text { Aug. } 20 \\
\text { Sept. } 20 \\
\text { Oct. } 20 \\
\text { Nov. } 20\end{array}$ & $\begin{array}{r}53 \\
83 \\
100 \\
100 \\
100\end{array}$ & $\begin{array}{r}13 \\
18 \\
41 \\
89 \\
100\end{array}$ & $\begin{array}{r}15 \\
31 \\
52 \\
98 \\
100\end{array}$ & $\begin{array}{r}13 \\
25 \\
50 \\
98 \\
100\end{array}$ & $\begin{array}{r} \\
38 \\
82 \\
100 \\
100\end{array}$ \\
\hline
\end{tabular}

ing laterals present at the time of transplanting and new roots which originated near the ends of cut laterals. The majority of new growth on trees which received no root pruning was of the first type. Essentially all new root growth on root-pruned trees was of the second type. 
There were significant differences in length of absorbing lateral roots due to date, seed source, and treatment (Figure 2). Also, all second-and third-order interactions were significant (Appendix Table 1). There was very little new lateral root elongation on any provenance transplanted in July and August. Growth became progressively greater after September and October transplanting and then leveled off in November. All monthly differences except the July-August and October-November comparisons were significant.

\section{TABLE 4}

\section{Loteral Root Length of Scotch Pine Provenances One Month After Transplanting With Various Intensities of Root Pruning}

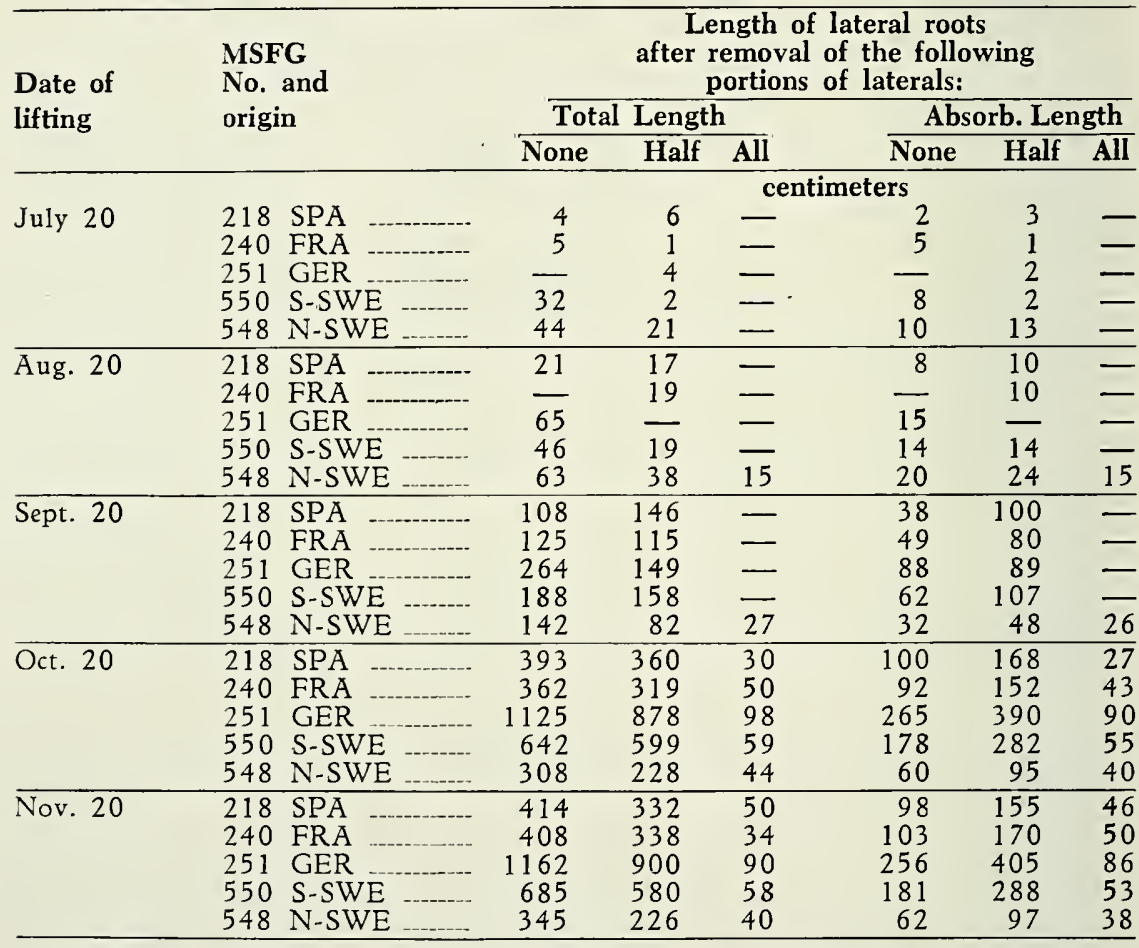

There were pronounced differences among sources in the total length of absorbing laterals produced by the end of the season (November). German seedlings had the greatest absorbing lateral root extent. South-Swedish ones had the next greatest amount and north-Swedish trees the least (Table 4: Figure 2). Root pruning affected the actual length of absorbing laterals produced but did not affect the ranking of seed sources. 


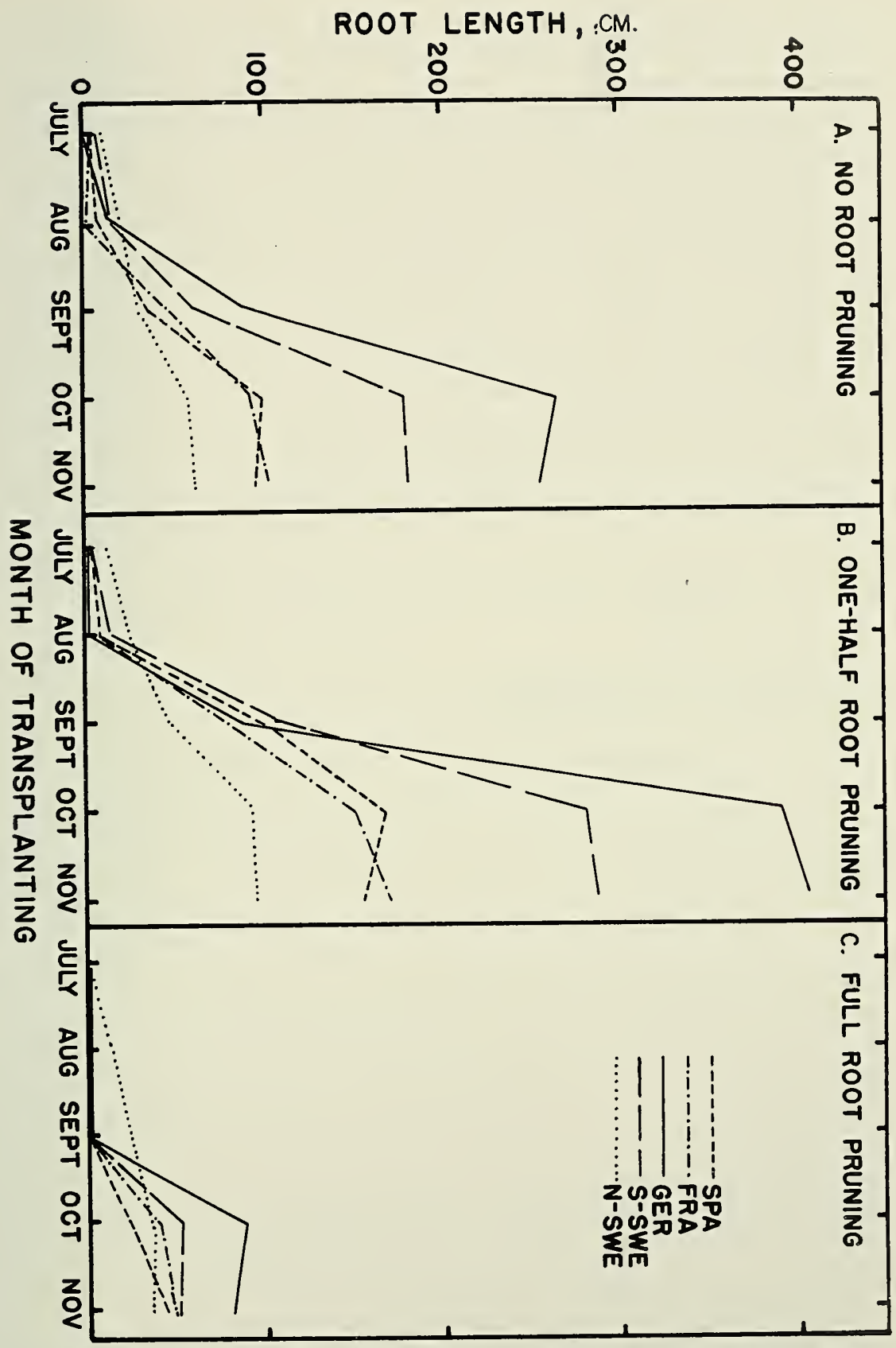

Figure 2. Length of absorbing (white) roots of Scotch pine as affected by date of transplanting, intensity of root pruning at transplanting time and provenonce. 
The ranking of seed sources did vary with transplanting date. North-Swedish trees had the longest absorbing laterals after the July and August transplantings and the least amount of absorbing laterals from September on. German seedlings had intermediate absorbing lateral lengths after the first two transplantings but the greatest amount for trees transplanted in September or later.

Average length of absorbing laterals was significantly affected by intensity of root pruning. It was greatest on trees receiving half-root pruning and least on those which were fully root-pruned (Table 4; Figure 2). Treatment-time and treatment seed-source interactions were also significant. For trees transplanted in July and August, absorbing lateral lengths were approximately the same for trees which had lost half their laterals as for those which had not been root pruned. After October and November transplantings absorbing lateral lengths were approximately 50 per cent greater if trees had lost half their laterals than if no root pruning had been done. Increases in absorbing lateral lengths on half root-pruned trees were least ( 45 per cent) for German and north-Swedish trees and greatest ( 75 per cent) for the French and Spanish provenances.

\section{Discussion and Conclusions}

\section{RELATION OF TOP TO ROOT GROWTH}

During the period of most active height growth (July-September) root growth was relatively slight. It was not until after terminal shoot growth had slowed down or was completed that the majority of the root growth took place (Figure 1). Nearly half the total root elongation occurred during September and October on trees from northSweden. During that same period the proportion of total root growth was approximately 60,66 , and 70 per cent, respectively, for trees from France, south-Sweden and Spain. Trees from Germany had the highest percentage of total root growth during this interval; 72 per cent of root elongation took place after the completion of height growth in September. These relationships can be stated statistically by correlations based on date-seedlot-treatment means for all five transplanting periods as items. The correlation coefficient between heights and total lateral root length (for trees with no root pruning) was -0.87 . Those between height and absorbing lateral roots were -0.85 and -0.82 . respectively, for trees with no and half-root pruning.

Similar trends in shoot versus root growth have been found in citrus and other fruit trees: Norway and Sitka spruce: European larch; 
red, white, Scotch, longleaf, slash, loblolly and shortleaf pines (Harris, 1929; Stevens, 1931; Laing, 1932; Kienholz, 1934; Turner, 1936; Huberman, 1940; Marloth, 1949; Reed and MacDougal, 1937). This inverse correlation between periods of active height and root growth is apparently associated with availability of manufactured carbohydrates. Growth of the Scotch pine seedlings used in this study was dependent initially on food materials stored in the seed, then on currently manufactured photosynthate, with little or none available for storage. Initially this photosynthate was used primarily for top growth. Kramer and Kozlowski (1960), reviewing earlier work, reported a tendency toward polarity in translocation of food in plants. Carbohydrates and other metabolites tend to move toward actively growing regions at the expense of more slowly growing regions, including root systems. The cause of this apparent polarity in translocation is not fully understood. Kramer and Kozlowski felt that the level of auxin production partly controls the direction of translocation through its effects on metabolic activity.

\section{RELATION OF SURVIVAL TO ROOT GROWTH}

Survival was closely correlated with the length of the root system at the time of transplanting and the growth of new roots after transplanting. During the early part of the growing season root lengths were very low and neither the length present at transplanting nor the new growth after transplanting was sufficient to supply the moisture needed by the actively growing trees. Of the five seedlots transplanted during July and August only seedlings from northern Sweden survived even moderately well and that was the origin with the largest root system at time of transplanting and the most root growth during the subsequent months.

Of the trees transplanted during September, those with half their root systems removed actually produced more absorbing roots during the subsequent month than did unpruned trees. As transplanting was done later in the fall, the amount of lateral growth increased and height growth decreased. Survival of trees transplanted in October and November was 100 per cent for all trees which had no or half-root pruning. Trees with all laterals removed at transplanting time could produce relatively little new root growth in the subsequent month and did not survive well except after the last transplanting.

Time of completion of height growth also apparently affected survival. Seedlings from northern Sweden survived as well or better than those of all other sources after all treatments and times of transplantings although they had the most lateral roots only during the early 
part of the season. The early completion of height growth of this source may have accounted for its good survival after later transplantings. Studies on other trees (reviewed by Kramer and Kozlowski, 1960) have shown that water metabolism and transpirational losses are greatest during the season of active height growth. This reduced water intake and loss for north-Swedish trees apparently counterbalanced their relatively small root systems.

E. C. Stone and his associates (Stone, 1955; Stone et al., 1959a. $1959 b, 1962$ and 1963) have studied seasonal variation in root regeneration of ponderosa pine and Douglas-fir. Trees transplanted in late spring and early summer had the lowest root regenerating potential and survival rates. Both increased gradually in early fall, sharply in late fall, and stayed constant until early spring. There were genetic differences in ponderosa pine, with high-elevation sources having the most rapid rate of increase in root regeneration potential and survival per cent in the autumn. This is similar to the trend found in this study in which seedlots from the coolest climates developed the highest survival potential earliest in the season.

\section{RECOMMENDATIONS FOR FIELD PRACTICE}

Nurserymen have practiced partial root pruning for many years, usually doing this one year prior to field planting on the theory that new laterals would develop during the ensuing season. This is undoubtedly good practice. Extensive root pruning at the time of fieid planting has not been generally recommended unless root systems are unusually large and can not be planted conveniently. However, results indicate that partial root pruning at the time of transplanting could be very beneficial in stimulating more new absorbing roots than might grow on the intact root system. The desirability of removing as much as one-half of the root system might be questionable. A number of studies, including those of Addoms (1946) and Kramer (1946), have shown that although the rate of water and nutrient absorption is greatest through the unsuberized, white area of the root systems, considerable quantities of these materials can move through suberized roots as well. The best root-pruning treatment would probably be one that provided a large number of severed lateral root tips without appreciably reducing the total length of the lateral root system.

\section{Summary}

Nursery grown seedlings of five provenances of Scotch pine from widely separated portions of the species range in western Europe were transplanted at monthly intervals for the first five months after seed, 
germination. Three intensities of root pruning were used at the time of transplanting. There were significant differences between provenances in seasonal patterns of top growth, survival, root growth and the ability of seedlings to regenerate new root systems.

A definite inverse periodicity in root and top growth was noted for all origins. During the period when top growth was most active, root elongation and root regeneration were relatively slight. It was not until after terminal shoot growth began to slow down or was completed that the majority of root growth or root regeneration took place.

Survival was closely correlated with the amount of roots present at transplanting and the growth of new roots after transplanting. During the early part of the growing season neither the amount of root present at transplanting nor new growth after transplanting was sufficient to supply moisture to the actively growing trees. Survival was very low. After the major increase in root growth which took place after height growth was completed, survival increased markedly.

Seasonal patterns of survival and root growth were closely correlated with the provenances used. After July and August transplantings, survival was somewhat better for seedlings from northern and southern Sweden. These provenances were also found to have the most rapid initial rates of root growth and root regeneration. Survival of seedlings from north-Sweden reached 100 per cent after the September transplanting and after the October transplanting for the other provenances.

Intensity of root pruning was found to affect survival and root regeneration after transplanting. It was significantly lower for trees which had received full-root pruning than for those which had received no or half-root pruning. No significant differences in average or periodic survival were noted between seedlings receiving no or half-root pruning. However, seedlings which had been half root-pruned produced significantly greater amounts of new root growth after transplanting than did trees which had not been root-pruned. 


\section{Literature cited}

Addoms, R. M. 1946. Entrance of water into suberized roots of trees. Plant Phys. 21: $109-111$.

Brown, J. H. 1967. Effect of time of summer pruning on limb development and shoot growth of five geographic origins of Scotch pine. W. Va. Univ. Agr. Exp. Sta. Bul. 543.

Gibbs, R. D. 1959. Patterns in the seasonal water content of trees. In the Physiology of Forest Trees by K. V. Thimann, W. B. Critchfield, and M. H. Zimmerman (Editors). Ronald Press Company, New York. pp. 43-69.

Harris, G. H. 1929. The influence of top on root as determined by root respiration in young fruit trees. Proc. Am. Soc. Hort. Sci. 26: 320-334.

Huberman, M. A. 1940. Normal growth and development of southern pine seedlings in the nursery. Ecology 21:323-334.

Kienholz, R. 1934. Leader, needle, cambial and root growth of certain conifers and their relationships. Bot. Gaz. 96: 73-92.

Kozlowski, T. T. 1943. Transpiration rates of some forest tree species during the dormant season. Plant Phys. 18: 239-251.

Kramer, P. J. 1932. The absorption of water by root systems of plants. Am. Jour. Bot. 19: 148-164.

1943. Amount and duration of growth of various species of tree seedlings. Plant Phys. 18: 239-251. 21: $37-41$. Absorption of water through suberized roots of trees. Plant Phys.

and T. T. Kozlowski. 1960. Physiology of Trees. McGraw-Hill Book Company, Inc., New York.

Laing, E. V. 1932. Studies on tree roots. For. Comm. Bull. 13, London.

Marloth, R. H. 1949. Citrus growth studies. I. Periodicity of root-growth and topgrowth in nursery seedlings and budlings. Jour. Hort. Sci. 25: 50-57.

Neff, M. S. and E. O'Rourke, Jr. 1951. Factors affecting the initiation of new roots in newly transplanted tung trees. Proc. Am. Soc. Hort. Sci. 57: 186-190.

Reed, H. S. and D. T. MacDougal. 1937. Periodicity in the growth of orange trees. Growth 1:371-373.

Ruby, J. L. 1964. The correspondence between genetic, morphological, and climate variation patterns in Scotch pine. PhD Thesis, Michigan State University.

Stevens, C. L. 1931. Root growth of white pine (Pinus strobus L.). Yale Univ. Sch. For. Bull. 32.

Stone, 1955. Poor survival and the physiological condition of planting stock. For. Sci. 1: $90-94$.

J. L. Jenkinson and S. L. Krugman. 1962. Root regeneration potential of Douglas-fir seedlings lifted at different times of the year. For. Sci. 8: 288-297.

and G. H. Schubert. 1959a. Root regeneration of ponderosa pine seedlings lifted at different times of the year. For. Sci. 5: 322-332.

and $1959 \mathrm{~b}$. The physiological condition of ponderosa pine (Pinus ponderosa Laws.) planting stock as it affects survival after cold storage. J. For. 57: $838-841$. 
R. W. Bensler, F. J. Baron, and S. L. Krugman. 1963. Variation in root regeneration potentials of ponderosa pine from four California nurseries. For. Sci. 9: 217-225.

Turner, L. M. 1936. Root growth of seedlings of Pinus echinata and Pinus tæda. U. S. D. A. Jour. Agr. Res. 53: 145-149.

Wilcox, H. 1955. Regeneration of injured root systems in noble fir. Bot. Gaz. 116 : 221-234.

Wright, J. W. and W. I. Bull. 1963. Geographic variation in Scotch pine, results of a 3-year Michigan study. Silvæ Genetica 12: 1-25.

S. S. Pauley, R. B. Polk, J. J. Jokela, and R. A. Read. 1966. Performance of Scotch pine varieties in the north central region. Silvæ Genetica 15: $101-110$. 


\section{APPENDIX}

APPENDIX TABLE 1

Analyses of Variance for Survival, Height, and Length of Absorbing

Portions of Lateral Roots of Scotch Pine Seed Sources

One Month After Transplanting With Various

Intensities of Root Pruning

\begin{tabular}{|c|c|c|c|}
\hline \multirow[b]{2}{*}{ Source of variation } & \multirow{2}{*}{$\begin{array}{l}\text { Degrees of } \\
\text { freedom }\end{array}$} & \multicolumn{2}{|c|}{ F ratios for } \\
\hline & & Survival & Height \\
\hline Replication & 3 & $\overline{70}$ & $\overline{70}$ \\
\hline Date of lifting & 4 & $572.0 * *$ & $370.6 * *$ \\
\hline Error a & 12 & $\overline{13} 8 * *$ & \\
\hline Seed Source & 4 & $13.8 * *$ & $409.3 * *$ \\
\hline $\begin{array}{l}\text { Source } x \text { Date } \\
\text { Error } b\end{array}$ & $\begin{array}{l}16 \\
60\end{array}$ & $3.0 * *$ & $32.9 * *$ \\
\hline Treatment & 2 & $59.8 * *$ & 2.9 \\
\hline Treatment $x$ Date & 8 & $7.8 * *$ & .5 \\
\hline Treatment $x$ Source & 8 & 1.6 & .2 \\
\hline Treatment $\mathrm{x}$ Date $\mathrm{x}$ & & & \\
\hline Source & 32 & 1.4 & .4 \\
\hline Error c & 150 & - & - \\
\hline
\end{tabular}

** Significant at 1 per cent level.

\section{APPENDIX TABLE 2}

Analyses of Variance for Total Length of Lateral Roots of Scotch Pine Seed Sources Measured One Month After

Transplanting at Various Dates (a)

Source of variation

Degrees of freedom

Total length of lateral roots

F ratio

\begin{tabular}{|c|c|c|}
\hline \multicolumn{3}{|l|}{ Replication } \\
\hline Date of lifting & 2 & $105.3 * *$ \\
\hline Error a & 6 & \\
\hline Seed Source & 4 & $89.3 * *$ \\
\hline Source x Date & 8 & $12.6 * *$ \\
\hline Error b & 36 & \\
\hline$-1-1-1-1-1-1-1-1-1$ & 1 & - \\
\hline Treatment $x$ Date & 2 & - \\
\hline Treatment $x$ Source & 4 & - \\
\hline Treatment $x$ Date $x$ Source & 8 & - \\
\hline Error c & 45 & - \\
\hline
\end{tabular}

(a) Due to high mortality after the July and August transplantings this variable was analyzed for only a portion of the data.

** Significant at 1 per cent level. 

